\title{
A STRATEGY TO PROMOTE THE COMPETITIVENESS OF MICRO, SMALL AND MEDIUM ENTERPRISES (MSME) DURING THE CONDITION OF COVID 19 PANDEMICS
}

\author{
Rahmadani ${ }^{1 *}$, Jefriyanto ${ }^{2)}$ \\ STIM Sukma Medan, Indonesia ${ }^{I)}$, STIE Mahaputra Riau, Indonesia ${ }^{2)}$ \\ 02rahmadani@gmail.com ${ }^{l)}$,jefriinfo@gmail.com ${ }^{21}$
}

\begin{abstract}
The research is aimed to review competitiveness strategies of Micro, Small, and Medium Enterprises (MSME) during the pandemic of Covid 19 to the MSME creative industries of Kp. Pelintahan notably. This research used primary and secondary data and used a descriptive qualitative approach for criticism to analyze the latest problems of MSME creative industries in this pandemic of Covid 19, which used semi-structured interviews, participative observation, and questionnaires for data accumulation technic. Then used AHP (Analytical Hierarchy Process) method and continued with SWOT analysis to formulate a strategy for solving it. The respondence of this research is about ten employees of MSME creative industries Kp. Pelintahan. The result of SWOT analysis is about 0,49 for IFAS and -1,54 for EFAS. Based on SWOT Matrix, the MSME Creative Industries position in Kp. Pelintahan is on 2nd Quadran for rating, which MSME Creative Industries employees of Kp. Pelintahan can take advantage of even a little strength to minimize a terrifying threat. The primary strategy is the Diversification Strategy with their salespeople to market their products MSME Creative Industries Kp. Pelintahan, which the market is reached out of Sumatera except for Lampung.
\end{abstract}

Keywords: MSME, Creative Industries, Analytical Hierarchy Process, Strengths Weakness Opportunities Threats.

*Corresponding author :

Email: 02rahmadani@gmail.com

DOI: https://doi.org/10.33369/j.akuntansi.11.3.197-208

\section{INTRODUCTION}

Covid-19 is no stranger to the ears of the whole community. An epidemic of global concern. Wuhan, a city in Hubei Province, China, suddenly became famous throughout. China is the first country to report this virus. December 8, 2019, the first confirmed case of Covid-19 in China based on the 37 WHO says on the Covid-19 situation. WHO declared a global public health emergency on January 30, 2020. On February 11, 2020, WHO announced that this virus would be known as Covid-19. On January 13, 2020, Thailand became the first country outside China to report a Covid-19 case.

Meanwhile, France became the first country in Europe to report three cases of Covid19 on January 25, 2020. On March 2, 2020, President Joko Widodo officially announced the first case of Covid-19 in Indonesia. Two Indonesian citizens who tested positive for the virus made contact with Japanese citizens who came to Indonesia. For the first time, on March 11, 2020, an Indonesian citizen died from Covid-19. From then on, Covid-19 cases continued to increase in Indonesia.

The Covid-19 pandemic has significantly impacted all aspects and sectors of life for the world community, including Indonesia. Especially for the economic sector, Covid-19 has exacerbated economic disparities that existed before the existence of Covid-19. Finance Minister Sri Mulyani Indrawati said there were three significant impacts of this pandemic on the economy. First, the effect on household consumption or purchasing power fell deeply, even though 60 per cent supported the economy. Second, due to Covid-19, investment has also weakened due to uncertainty. Third, Indonesian exports have experienced a decline wherein several destination countries have stopped. This is because the entire world is experiencing an economic downturn (www.liputan6.com, 2020) 
MSME has intensely felt the Covid-19 outbreak which has an impact on the economic sector. The Covid-19 pandemic has put MSME in a stagnant position, and many have even ended up going bankrupt (Arianto, 2020). Where the economic business most affected by the Covid-19 pandemic is MSME (Rosita, 2020). MSME based on (UU No 20, 2008) on Micro, Small and Medium Enterprises (MSME), Micro Enterprises are productive businesses owned by individuals and business entities. Furthermore, Small Business is a compelling economic business that stands alone which is carried out by individuals or business entities that are not subsidiaries or not a branch of a company that is owned, controlled, or is a part, either directly or indirectly, of a Medium or Large Business. Meanwhile, Medium Enterprises are productive economic enterprises that are independent, carried out by individuals or business entities that are not subsidiaries or branches of companies owned, controlled, or are part of, either directly or indirectly, of Small or Large Enterprises.

The creative industry is an industry that focuses on creating goods and services by relying on the creativity, skills and talents of individuals to create prosperity and employment (Departemen Perdagangan RI, 2008). There are 18 creative industry subsectors developed in Indonesia, namely animation, architecture, design, photography, music, crafts, culinary, fashion, research and development, publishing, film, advertising, interactive games, performing arts, fine arts, information technology, television and radio, video (Suparmin, Roniwijaya, Priyanto, \& Setiadi, 2017).

MSME have a very strategic role in the Indonesian economy. One category of business scale structurally occupies a significant position. Since the era of the monetary crisis, which was marked by the devaluation of the rupiah, decreasing purchasing power, uncontrolled inflation and increasing production costs, MSME has been at the forefront of efforts to move the real sector. In the midst of the turmoil, most MSME were able to show extraordinary performance (Karya Bersama Fakultas Ekonomi Universitas Surabaya dan Forum Daerah UKM Jawa Timur, 2007).

Data from the Indonesian Ministry of Cooperatives and Small and Medium Enterprises in 2019 shows that the number of MSME business units is $99.9 \%$ of the total business units or 65.4 million units. MSME absorb $96.92 \%$ of full employment, $89.04 \%$ of which are in the micro sector, $4.81 \%$ in the small business sector, $3.07 \%$ in the medium business sector and contribute $60 \%$ to gross domestic product (Kemenkop dan UMKM, 2019). Strategies are needed to increase the competitiveness of MSME during the Covid-19 pandemic. In terms of improving their performance, MSME actors are required to have qualified knowledge management and absorptive capacity. Product absorption, availability of raw materials, and distribution processes have been affected by the Covid-19 outbreak in MSME. The conditions of the Covid19 pandemic that currently make MSME need special attention to increasing the competitiveness (Fitriyani, Sudiyarti, \& Fietroh, 2020). Strategy in competition is obtained through developing internal and external conditions (Hartanto \& Kholil, 2018) in line with what has been stated by Istianingsih, Salim, \& Defit (2019) that the sustainability of MSME can be built by paying attention to internal and external factors.

In previous research related to strategies to increase the competitiveness of MSME, there were different results. It is necessary to develop the right strategy (Diniaty et al., 2019). Research conducted (Kurdi \& Firmansyah, 2020) (Rahmadani et al., 2021) reveals that in increasing competitiveness, the strategy to build good closeness to customers and increase product innovation. Strategy in increasing competitiveness is a strategy growth by utilizing all the strengths of MSME ((A. Ariani \& Utomo, 2017); (Alyas \& Rakib, 2017). In contrast, (Narto \& HM, 2020) state the alternative strategy is to maintain prices and increase product quality, a difference to (Mahmudi \& Sodiq, 2020) states that increasing the competitiveness of MSME with lower prices but still product quality. Problems in the development of MSME are human 
resources (Meliala, Matondang, \& Sari, 2014); (Andriani, Astari, Budhiarti, \& Zachary, 2017). The analysis results were carried out using the IFAS-EFAS matrix, SWOT matrix and Cartesian SWOT diagram. The strategy obtained is quadrant IV strategy, namely the ST strategy, which is a strategy to utilize strength factors to overcome threat factors. Its implementation is through improving product quality (Anggraeni, Sunarti, \& Mawardi, 2017).

The phenomena, theories, and research gaps are disclosed above. The researchers are interested in researching Strategies for Increasing the Competitiveness of Micro, Small and Medium Enterprises (MSME) in the Covid-19 Pandemic Condition. Case Study on MSME Creative Industry Kp Pelintahan, Sei Rampah District, so that it is known what the MSME Creative Industry Kp should implement the best strategy. Pelintahan is amid the Covid-19 pandemic.

\section{RESEARCH METHODS}

This research is a qualitative descriptive study. The research method, which is based on postpositivism philosophy, is used to examine the condition of natural objects, where the researcher is the critical instrument (Sugiyono, 2012). This research provides a systematic overview of scientific information related to strategies for increasing the competitiveness of MSME in the Covid-19 pandemic conditions. The study was conducted at the Creative Industry MSME located in the Kp Pelintahan, Sei Rampah District, Serdang Bedagai Regency. The respondents who were the subjects of this study were 10 MSME players in the Creative Industry, Kp Pelintahan, who have been running this business for more than ten years. Sources of data in this study are primary data and secondary data. The data collection techniques used in this study were: semi-structured interviews, participatory observation, and questionnaires. This semi-structured interview aims to find more open problems, where the interviewee is asked for his opinion. Researchers in the ongoing interview process need to listen carefully and take notes on what the informants say. Data analysis steps in the case study (Akmal, 2011), namely?:

a. Choose a social situation.

Choosing a social situation is the first step that researchers must take before going directly to conduct research.

b. Carry out participant observation.

Participant observation: At this stage, the researcher is directly involved in the daily activities of the people used as sources of research data.

c. Conducting observations and interviews.

Observation and interviews, observation is a data collection technique where researchers must observe the spaciousness directly. At the same time, the interview is a question and answer conducted by researchers with informants now to obtain information related to the problem under study.

d. Make descriptive observations.

Descriptive observation, at this stage, the researcher has not brought the problem to be studied. So that the researchers conducted a thorough exploration, doing a description of everything that was seen, heard, and felt. At this stage, the researcher also produces the first conclusion.

e. Perform domain analysis.

Domain analysis, this stage is carried out to describe all that is found in descriptive observations.

f. Make a focused observation.

Focused observation, the researcher conducts a mini-tour of compliance at this stage, namely words that have been reduced to focus on specific aspects.

g. Perform taxonomic analysis. 
After conducting focused observations, the taxonomic analysis then shows taxonomic research so that researchers can find the focus to be studied in depth.

h. Make selected observations.

Selected observation, at this stage, the researcher describes the focus found so that the research data is more detailed.

i. Performs a component analysis.

Componential analysis this analysis is a method of searching systematically related to cultural categories. After conducting this analysis, the researcher has found the characteristics, differences and similarities between types and found the relationship between one kind and another.

j. Perform a theme analysis.

Theme analysis, this analysis is based on assumptions. This analysis is conducted for researchers to find a deep understanding or hypothesis.

k. Cultural findings.

Cultural findings, after conducting a theme analysis, researchers found artistic conclusions of the research that had been done

1. Writing qualitative research reports.

The last data analysis step is that the researcher writes a qualitative research report on the cultural findings obtained.

Based on the data analysis steps above, the qualitative research process, after entering the field, begins with determining a key informant who is an authoritative and trustworthy informant who can "open the door" for researchers to join the research object. Furthermore, the researchers conducted interviews with informants and recorded the results of the discussions. Then the attention of researchers on the thing of research and began to ask descriptive questions and analysis of the results of the interviews. Based on the results of the interview, a domain analysis was conducted. In the next step, the researcher has determined the focus and carried out a taxonomic study. Next, the researcher asked contrasting questions, which was followed by componential analysis. Then the results of the componential analysis, the researchers found cultural themes. Based on these findings, the researchers conducted a research report (Sugiyono, 2012).

Furthermore, data collection was carried out through questionnaire techniques, using the AHP (Analytical Hierarchy Process) method. Analytical Hierarchy Process is a method for solving problems in making decisions in uncertain situations and with various criteria (Chou \& $\mathrm{Yu}, 2013$ ). AHP conducted pairwise comparisons to assess alternative measures (Görener, Toker, \& Uluçay, 2012). AHP aims to calculate the priority weight of the existing criteria. Then if the results are consistent, namely CR $<=0.1$, then a SWOT analysis can be continued (Strengths, Weaknesses, Opportunities, Threats). The SWOT analysis is structured to create an appropriate strategy for increasing competitiveness through weighting scores. (Görener et al., 2012) revealed that the SWOT analysis provides a basic outline for conducting a decision situation analysis. The following is figure 1 related to competitive strategy (Ariani, 2017):

The strategy of an organization must pay attention to internal factors as well as external factors. Internal factors are factors from within the company, and external factors are factors from outside that affect an organization. The preparation of internal factors includes an assessment of strengths and weaknesses, namely the personal values of the critical elements. Meanwhile, external factors related to opportunities and threats are related to the expectations of the wider community. An organization is influenced by external factors, such as political, cultural, and legal and regulatory factors. So in formulating a strategy, these factors can influence. 


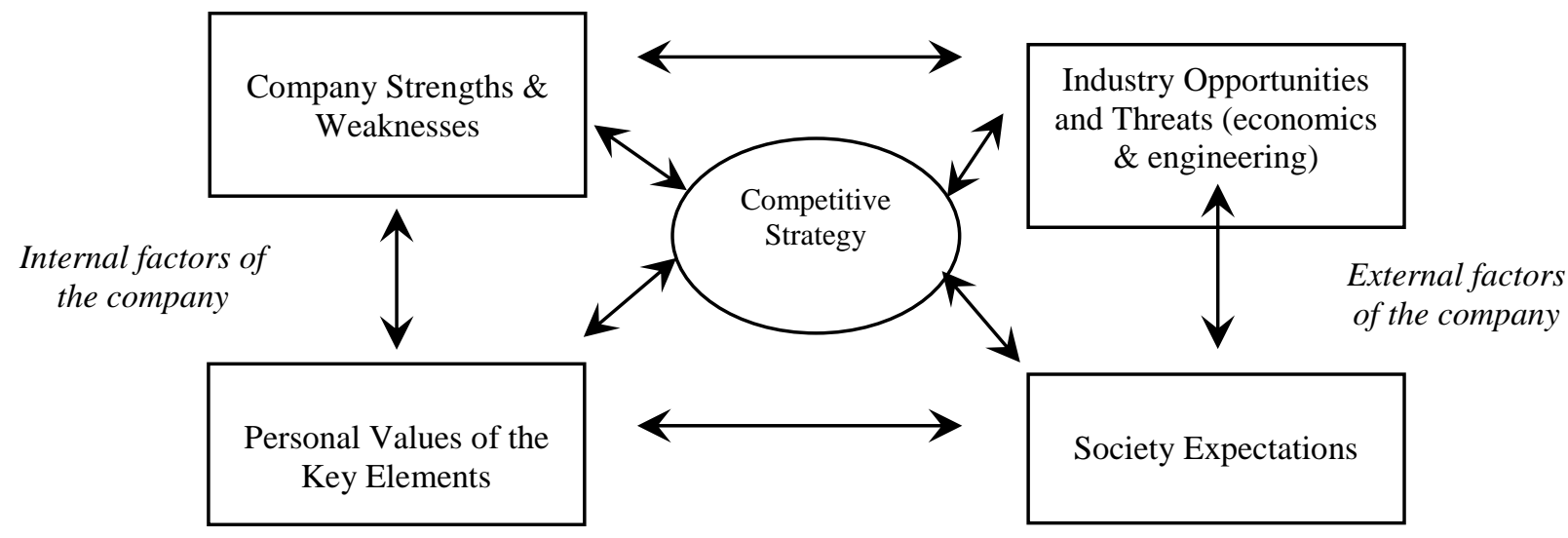

Figure 1. Competitive Strategy

Source: Haksever, et. al., 2000

\section{RESULTS AND DISCUSSION}

MSME Creative Industry of Kp Pelintahan is a Creative Industry MSME which is located in the Kp Pelintahan, Sei Rampah District, Serdang Bedagai Regency, North Sumatra Province. The MSME creative industry operated in 1980 and produced a product in a palm fibre that Mr Semo ran. Then the effort was followed by the surrounding community in the Kp Pelintahan until it continues to develop until now. $80 \%$ of the livelihoods of the local community come from these creative industry business activities. Creative Industry Kp Pelintahan is an industry that manages fibres, coconut coir, wire, nets, sticks, sponges, and ropes. The products produced are household cleaning products such as fibres, coir brushes, dishwashing nets, clothespins, foot mats, palm brooms, broomsticks, mop brooms, water filters, ropes, and also produce fish grills.

The market share for products produced by the Creative Industry Kp Pelintahan was initially only in the Tebing Tinggi area and around Medan. Still, now the market share includes Sibolga, Parapat, Nias and other North Sumatra areas, besides that it has also expanded beyond the province of North Sumatra, namely Aceh, Pekanbaru, Jambi, Padang, Bengkulu and Palembang. Entrepreneurs of the MSME Creative Industry of Kp Pelintahan obtain products in 2 ways: producing their own goods through owned craftsmen and buying goods made by local craftsmen. Where later, the handicraft products are sold to sales (distributors).

The organizational structure is a schema that shows the main aspects and relationships between the parts. The organizational structure of the MSME Creative Industry Kp Pelintahan can be seen in Figure 2 below. Where Creative Industry SMEs have craftsmen and also sales (distributors). Furthermore, this sales market the MSME products to shops/stalls.

Based on the research results found, details regarding the strengths, weaknesses, opportunities, and threats to the MSME Creative Industry Kp Pelintahan can be seen. The calculation of the score on the IFAS (Internal Factor Analysis Summary) is obtained from the multiplication of the weight with the rating. Weights are calculated, 0.0 (not important) to 1.0 (very important). The rating starts from number 1 (below average), number 2 (average), number 3 (above average), and number 4 (very good). Then the score value is obtained from the multiplication between the weight and the score. 


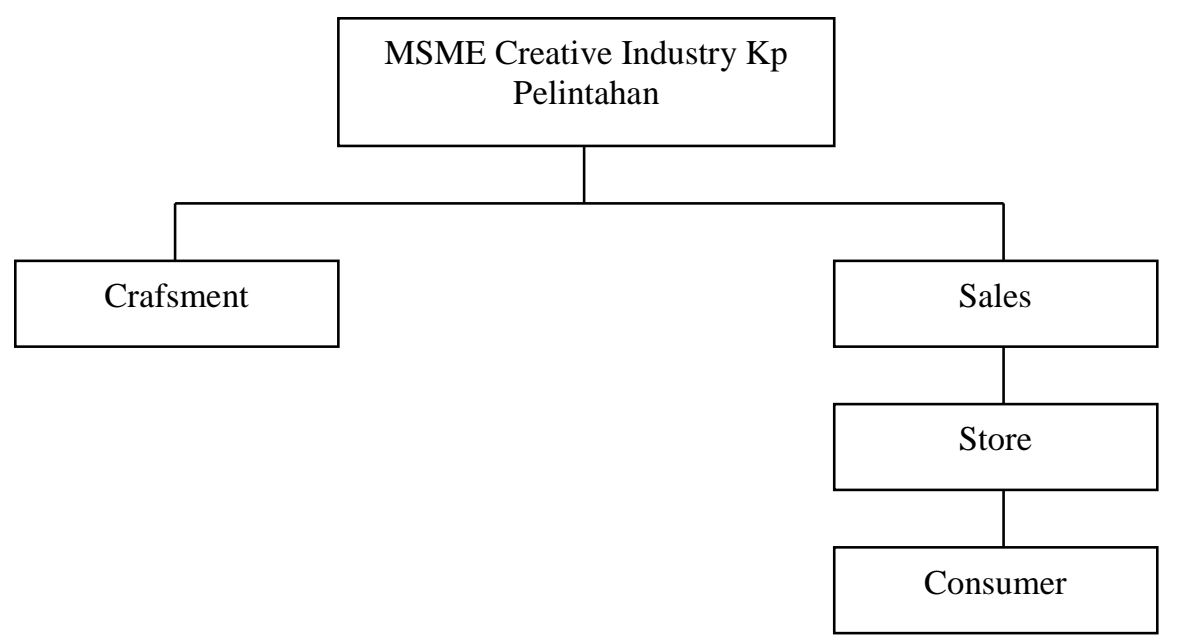

Figure 2. Organizational structure of the MSME Creative Industry Kp Pelintahan Source: Interviews Result, 2021

The following are the details of IFAS (Internal Factor Analysis Summary) MSME Creative Industry Kp Pelintah can be seen in these tables.

Table 1. Internal Factor Analysis Summary (IFAS)

\begin{tabular}{|c|c|c|c|}
\hline Strategic Factors & Quality & Rate & Score \\
\hline \multicolumn{4}{|l|}{ Strengths } \\
\hline 1. Have a business license & 0,01 & 3,5 & 0,05 \\
\hline 2. The market reach is very wide & 0,16 & 4,0 & 0,64 \\
\hline 3. Have a sales force & 0,25 & 4,0 & 1,00 \\
\hline $\begin{array}{l}\text { 4. Raw materials are easy to obtain, and the quality of } \\
\text { raw materials is consistent }\end{array}$ & 0,06 & 3,8 & 0,21 \\
\hline 5. $\quad$ Business location easily accessible & 0,04 & 3,9 & 0,14 \\
\hline Subtotal & & & 2,04 \\
\hline \multicolumn{4}{|l|}{ Weaknesses } \\
\hline 1. Does not have a patented brand & 0,02 & 1,6 & 0,04 \\
\hline 2. Limited Capital & 0,11 & 3,5 & 0,39 \\
\hline 3. Limitations in using technology & 0,03 & 2,1 & 0,07 \\
\hline 4. Material Prices & 0,23 & 3,7 & 0,85 \\
\hline $\begin{array}{l}\text { 5. There is still a lack of understanding of the } \\
\text { application of financial reports under the EMKM } \\
\text { Accounting Standard }\end{array}$ & 0,09 & 2,4 & 0,21 \\
\hline Subtotal & & & 1,55 \\
\hline TOTAL & & & 0,49 \\
\hline
\end{tabular}

Internal Factor Analysis Summary table above, the total Strengths is 2.04, and the total score is Weaknesses 1.55. That's the way; the IFAS score is obtained (Internal Factor Analysis Summary) of 0.49. Based on the results of the IFAS, there is a need for support from the government in the form of a one-stop service for MSME to make it easier for MSME to take care of all matters related to their business development. IFAS can be controlled through all programs carried out by the government through related agencies, either coaching or mentoring. MSME needs government support, where the government as a legal entity can develop MSME. The score calculation on the EFAS (External Factor Analysis Summary) is obtained from the multiplication of the weight and the rating. Following are details of EFAS (External Factor Analysis Summary) MSME Creative Industry Kp Pelintahan can be seen in this table. 
Table 2. External Factor Analysis Summary (EFAS)

\begin{tabular}{lccc}
\hline Strategic Factors & Quality & Rate & Score \\
\hline Opportunities & & & \\
\hline 1. Ease of transaction & 0,06 & 3,7 & 0,23 \\
\hline $\begin{array}{l}\text { 2. High consumption power of the community towards the need for } \\
\text { household cleaning tools }\end{array}$ & 0,13 & 4,0 & 0,53 \\
\hline 3. Government assistance program & 0,03 & 3,2 & 0,08 \\
\hline 4. Keep up with the times & 0,06 & 3,5 & 0,22 \\
\hline 5. Easy government bureaucracy & 0,02 & 2,4 & 0,05 \\
\hline Subtotal & & & 1,11 \\
\hline Threats & 0,30 & 4,0 & 1,20 \\
\hline 1. In general, economic conditions are felt to be difficult amid the & & & \\
$\quad$ conditions of the Covid-19 pandemic & 0,04 & 3,0 & 0,12 \\
\hline 2. The inflation rate is always increasing & 0,07 & 3,4 & 0,22 \\
\hline 3. Difficult to get third party funding with low interest & 0,26 & 4,0 & 1,04 \\
\hline 4. Prone to fraud & 0,03 & 2,0 & 0,06 \\
\hline 5. Security threat & & & 2,65 \\
\hline$\quad$ Subtotal & & $-1,54$ \\
\hline TOTAL & &
\end{tabular}

From table 2, it is known that the total Opportunities are 1.11, and the total score is threats 2.65. With this obtained an EFAS (External Factor Analysis Summary) score of -1.54. The results of the EFAS show that MSME still has shortcomings in getting government programs, from the many problems MSME can be used as programs by the government to support. Of course, all the opportunities that exist must be synchronized with the latest economy. Due to different economic conditions, various treatments are needed. The need for a new program that synergizes with economic conditions. Especially in the current pandemic economic conditions, where all industry players feel the impact of the spread of Covid-19.

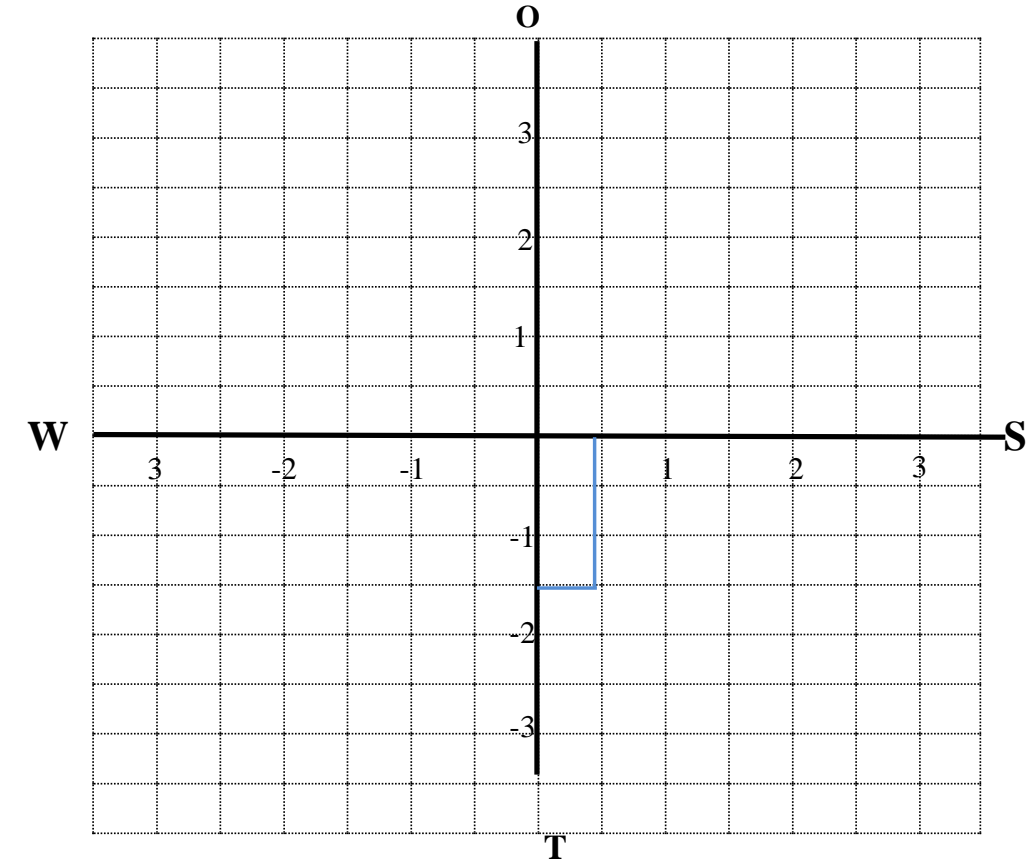

Figure 3. SWOT Position Matrix

In line with the research results (Setiawan et al., 2018), applying a dieresis strategy. Then from Figure 3 the SWOT matrix above, a system can be formulated to increase the 
competitiveness of the MSME Creative Industry Kp Pelintahan following the internal and external conditions of MSME, namely as follows:

Table 3. Matriks SWOT MSME Creative Industry Kp Pelintahan

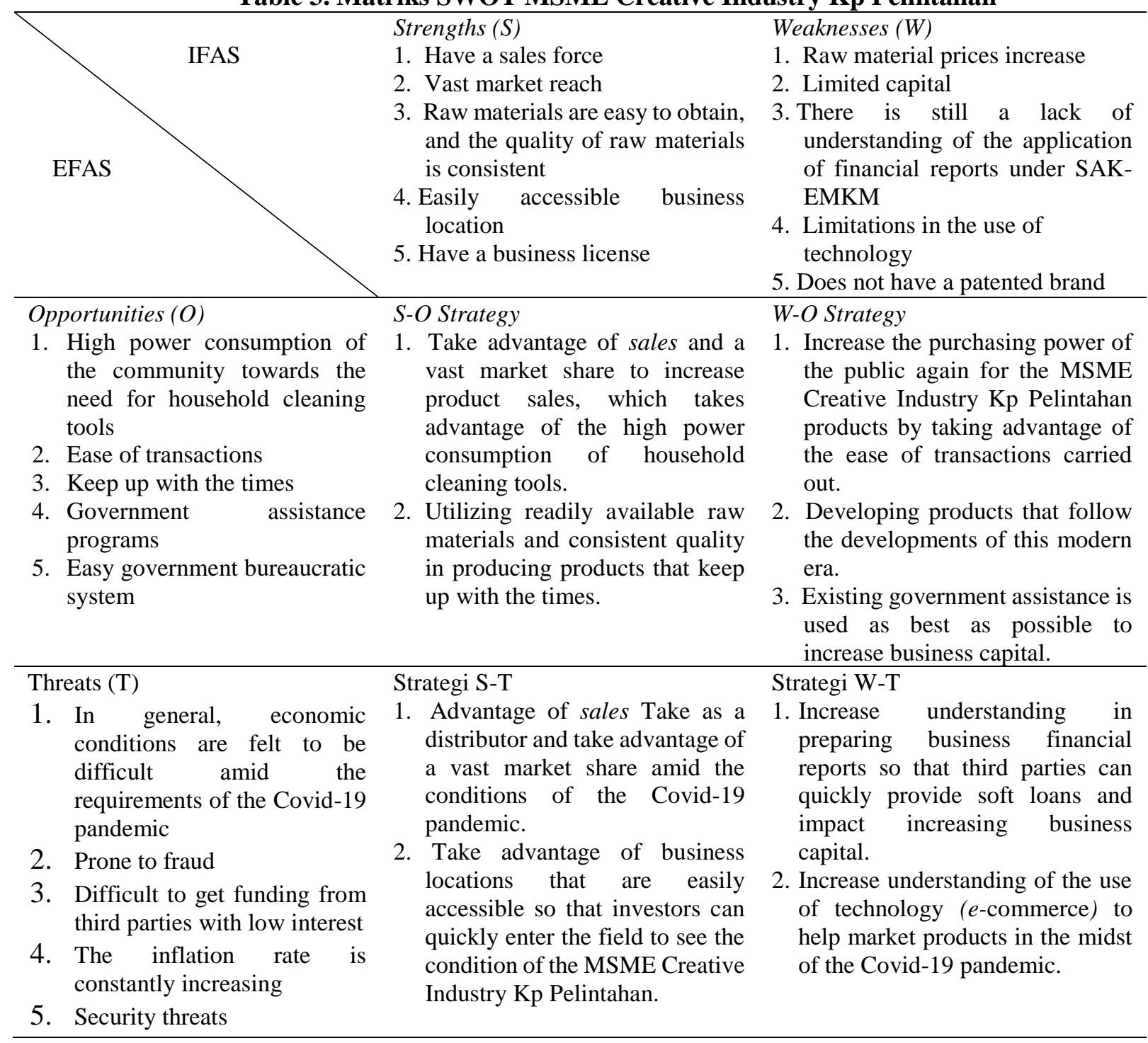

Based on the SWOT analysis above, internal factors, the biggest strength of the Creative Industry MSME Kp Pelintahan is having a sales force (sales) with a score of 1.00 , and the highest weakness is the price of raw materials rising with a score of 0.85 . While external factors, the most significant opportunity is the increased public consumption power for household cleaning tools with a score of 0.53 . The highest threat is that general economic conditions are difficult in the Covid-19 pandemic with a score of 1.20. Analysis of the effectiveness of marketing strategies shows a significant increase (Purnomo \& Hadi, 2018). In line with the research conducted (Rahmadani et al., 2021) (Mulyana et al., 2021) (Raharja \& Natari, 2021), marketing strategy through the use of technological advances is a "diamond" step during the Covid-19 pandemic by implementing digital marketing., SWOT analysis as a strategy to increase competitiveness needs to be re-evaluated to form good performance from within and from outside (Mashuri \& Nurjannah, 2020). 
The best strategy that the MSME Creative Industry Kp Pelintahan can apply is a SWOT analysis, namely the Strategy Strengths-Threats. ST strategy is to harness the power of the sales force. Currently, they can market MSME Creative Industry products in almost one island of Sumatra, except for Lampung, which was initially only in the city of Tebing Tinggi and the surrounding Medan. The salesforce owned by the MSME Creative Industry Kp Pelintahan is a force during the current Covid-19 pandemic. In the requirements of the Covid-19 pandemic with a role sales, the products of the MSME Creative Industry Kp Pelintahan could still be marketed. Another strategy is to take advantage of the location of the MSME Creative Industry Kp Pelintahan, which is easy to access so that investors can easily visit the business location and are sure to provide funding. In line with research results (Sutanto \& Sudantoko, 2012), business actors are still low in access to credit.

\section{CONCLUSIONS AND SUGGESTION}

The strategy to increase the competitiveness of MSME during the Covid-19 pandemic, which was carried out through the AHP (Analytical Hierarchy Process) method, then continued with a SWOT analysis, which is the results of a SWOT analysis conducted on MSME Creative Industries in Kp Pelintahan is in quadrant II. MSME Creative Industry Kp Pelintahan must be able to take advantage of strength to minimize existing threats. The primary strategy for increasing competitiveness amid the conditions of the Covid-19 pandemic is a diversification strategy by utilizing the strength of sales (force) owned to market MSME products for the Creative Industry Kp Pelintahan, where the market share reaches almost one island of Sumatra, except Lampung. Easy-to-obtain raw materials and consistent quality are also the strengths of the MSME Creative Industry Kp Pelintahan that need to be improved again. In addition, it utilizes a business location that is easily accessible so that investors can easily review the field to see the condition of the MSME Creative Industry Kp Pelintahan. Not only that, but the MSME Creative Industry Kp Pelintahan can also take advantage of all their strengths to overcome existing threats. Based on the results of this study, suggestions that can be given to MSME are that the final results of this study can be used as a reference in making decisions to improve the competitiveness of MSME in Kp Pelintahan, Sei Rampah District, Serdang Bedagai Regency. For further research, expand the object and scope of study to provide even more significant benefits where the limitation of this research is that it only examines the MSME Creative Industry Kp Pelintahan. 
A STRATEGY TO PROMOTE THE COMPETITIVENESS OF MICRO, SMALL AND MEDIUM ENTERPRISES (MSME) DURING THE CONDITION OF COVID 19 PANDEMICS

Rahmadani and Jefriyanto

\section{REFERENCES}

Akmal, T. A. (2011). Metodologi Penelitian Ekonomi Islam. Medan: La Tansa Press.

Alyas, \& Rakib, M. (2017). Strategi Pengembangan Usaha Kecil Dan Menengah Dalam Penguatan Ekonomi Kerakyatan (Studi Kasus Pada Usaha Roti Maros Di Kabupaten Maros). Sosiohumaniora, 19(2), 114-120. https://doi.org/10.24198/sosiohumaniora.v19i2.12249

Andriani, F. Y., Astari, D. I., Budhiarti, D., \& Zachary, K. M. (2017). Analisis Pengambilan Keputusan Strategi Pengembangan Industri Kreatif Kulit Ikan Pari Yogyakarta dengan Pendekatan SWOT dan AHP. Seminar Nasional IENACO, 288-295.

Anggraeni, P., Sunarti, S., \& Mawardi, M. (2017). Analisis Swot Pada UMKM Keripik Tempe Amel Malang Dalam Rangka Meningkatkan Daya Saing Perusahaan. Jurnal Administrasi Bisnis S1 Universitas Brawijaya, 43(1), 104-113. Retrieved from http://administrasibisnis.studentjournal.ub.ac.id

Ariani, A., \& Utomo, M. N. (2017). Kajian Strategi Pengembangan Usaha Mikro Kecil Dan Menengah (Umkm) Di Kota Tarakan. Jurnal Organisasi Dan Manajemen, 13(2), 99-118. https://doi.org/10.33830/jom.v13i2.55.2017

Ariani, D. W. (2017). Manajemen Operasi. Tanggerang Selatan: Universitas Terbuka.

Arianto, B. (2020). Pengembangan UMKM Digital di Masa Pandemi Covid-19. ATRABIS: Jurnal Administrasi Bisnis, 6(2), 233-247. https://doi.org/https://doi.org/10.38204/atrabis.v6i2.512

Chou, C. C., \& Yu, K. W. (2013). Application of a new hybrid fuzzy AHP model to the location choice. Mathematical Problems in 2013. https://doi.org/10.1155/2013/592138

Departemen Perdagangan RI. (2008). Pengembangan Ekonomi Kreatif Indonesia 2025: Rencana Pengembangan Ekonomi Kreatif Indonesia 2009-2015. Jakarta: Departemen Perdagangan Republik Indonesia.

Diniaty, D., Kusumanto, I., Roza, F., Husna, F. D., Hartati, M., \& Nofirza. (2019). Analisis Strategi Pemasaran dalam Upaya Meningkatkan Penjualan Ikan Salai Patin pada Kelompok XYZ. 6(November), 109-120. https://doi.org/10.31289/jkbm.v512.3080

Fitriyani, I., Sudiyarti, N., \& Fietroh, M. N. (2020). Strategi Manajemen Bisnis Pasca Pandemi Covid-19. Indonesian Journal of Social Sciences and Humanities, 1(No. 2), 87-95.

Görener, A., Toker, K., \& Uluçay, K. (2012). Application of Combined SWOT and AHP: A Case Study for a Manufacturing Firm. Procedia - Social and Behavioral Sciences, 58, 1525-1534. https://doi.org/10.1016/j.sbspro.2012.09.1139

Hartanto, A. B., \& Kholil, M. (2018). Analisis SWOT Sebagai Dasar Perumusan Strategi Pemasaran (Studi Kasus : Pada Perusahaan Trading PT. PTG). Jurnal Rekayasa Teknologi Industri Hijau, 1(2), 1-5. Retrieved from https://ejournal.unugha.ac.id/

Istianingsih, N., Salim, E., \& Defit, S. (2019). Strategi Sustainability UMKM Pisang Sale di Kabupaten Bungo dengan Metode SWOT dan Analytic Hierarchy Process (AHP). Prosiding Seminar Nasional Riset Information Science (SENARIS), I(September), 110. https://doi.org/10.30645/senaris.v1i0.14

Karya Bersama Fakultas Ekonomi Universitas Surabaya dan Forum Daerah UKM Jawa Timur. 
(2007). Kewirausahaan UKM Pemikiran dan Pengalaman. Yogyakarta: Graha Ilmu.

Kemenkop dan UMKM. (2019). Tabel 1 Perkembangan Data Usaha Mikro, Kecil, Menengah (UMKM) dan Usaha Besar (UB). 2018-2019.

Kurdi, M., \& Firmansyah, I. D. (2020). Strategi Peningkatan Daya Saing UMKM Di Kabupaten Sumenep Melalui E-Commerce. Jurnal Sains Sosio Humaniora, 4(2), 569-575. https://doi.org/10.22437/jssh.v4i2.11003

Mahmudi, A. A., \& Sodiq, F. (2020). Strategi Pengembangan UKM Menggunakan Kombinasi Metode AHP dan TOPSIS. 1(1), 1-11. Retrieved from http://journal.unirow.ac.id/index.php/curtina/article/view/210

Mashuri, \& Nurjannah, D. (2020). Analisis Swot Sebagai Strategi. Jurnal Perbankan Syariah, 1(1), 97-112. https://doi.org/https://doi.org/10.46367/jps.v1i1.205

Meliala, A. S., Matondang, N., \& Sari, R. M. (2014). Strategi Peningkatan Daya Saing Usaha Kecil dan Menengah (UKM) Berbasis Kaizen. Jurnal Optimasi Sistem Industri, Vol. 13(No. 2), 641-664.

Mulyana, A. E., Hidayat, R., Andayani, N. R., Zuliarni, S., Pratama, A. W., Septiana, M., ... Soebagiyo, S. (2021). Pengembangan UMKM Melalui Sosialisasi dan Penyuluhan Secara Digital untuk Menunjang Keberlangsungan Usaha di Masa Pandemi Covid-19. Jurnal Pengabdian Kepada Masyarakat Politeknik Negeri Batam, 3(1), 62-76. https://doi.org/https://doi.org/10.30871/abdimas\%20polibatam.v3i1.2685

Narto, N., \& HM, G. B. (2020). Penguatan Strategi Pemasaran Pudak di Tengah Pandemi Covid-19 untuk Meningkatkan Keunggulan Bersaing Usaha Mikro Kecil Menengah Kota Gresik. Jurnal INTECH Teknik Industri Universitas Serang Raya, 6(1), 48-54. https://doi.org/10.30656/intech.v6i1.2195

Purnomo, \& Hadi, Y. (2018). Analisis Swot Dan Strategi Pemasaran Untuk Meningkatkan Daya Saing UKM Es Puter Di Kota Malang. Kurawal - Jurnal Teknologi, Informasi Dan Industri, 1(1), 52-57. https://doi.org/10.33479/kurawal.2018.1.1.52-57

Raharja, S. J., \& Natari, S. U. (2021). Pengembangan Usaha Umkm Di Masa Pandemi Melalui Optimalisasi Penggunaan Dan Pengelolaan Media Digital. Kumawula: Jurnal Pengabdian Kepada Masyarakat, 4(1), 108. https://doi.org/10.24198/kumawula.v4i1.32361

Rahmadani, Wardayani, Nurlinda, Nurhayati, Supriyanto, Sugianto, ... Anggraini, D. (2021). Pendampingan UMKM Hebat dengan Inovasi Produk, Pemasaran Digital, dan Pengelolaan Keuangan Pada Usaha Cekeremes di Kecamatan Medan Tuntungan. JURPIKAT (Jurnal Pengabdian Kepada Masyarakat), 2(2), 147-157. https://doi.org/https:https://doi.org/10.37339/jurpikat.v2i2.637

Rosita, R. (2020). Pengaruh Pandemi Covid-19 Terhadap Umkm Di Indonesia. Jurnal Lentera Bisnis, 9(2), 109. https://doi.org/10.34127/jrlab.v9i2.380

Setiawan, A., Wahyuni, H. C., Studi, P., Industri, T., Teknik, F., \& Sidoarjo, U. M. (2018). Integrasi Metode SWOT Dan AHP Untuk Merumuskan Strategi Pemasaran (Studi Kasus : PT. Rattan Craft Indonesia ). 2(1), 12-19.

Sugiyono. (2012). Metodologi Penelitian Bisnis. Bandung: Alfabeta.

Suparmin, Roniwijaya, P., Priyanto, S., \& Setiadi, B. R. (2017). Eksplorasi sub-sub sektor industri kreatif di pusat-pusat keramaian kabupaten kulon progo. Studi Pendidikan Teknik Mesin, (January), 712-720. Retrieved from https://media.neliti.com/media/publications/174141-ID-eksplorasi-sub-sub-sektorindustri-kreat 
A STRATEGY TO PROMOTE THE COMPETITIVENESS OF MICRO, SMALL AND MEDIUM ENTERPRISES (MSME) DURING THE CONDITION OF COVID 19 PANDEMICS

Rahmadani and Jefriyanto

Sutanto, H. A., \& Sudantoko, D. (2012). Strategi Peningkatan Keberdayaan Industri Kecil Konveksi Dengan Analiysis Hierarchy Process (Ahp). JEJAK: Jurnal Ekonomi Dan Kebijakan, 5(1), 15-25. https://doi.org/10.15294/jejak.v5i1.4623

UU No 20. (2008). Undang-Undang Republik Indonesia Nomor 20 Tahun 2008 Tentang Usaha Mikro, Kecil, dan Menengah.

www.liputan6.com. (2020). Sri Mulyani: Corona Beri 3 Dampak Besar ke Ekonomi Indonesia. Retrieved from https://www.liputan6.com/bisnis/read/4292763/sri-mulyani-corona-beri3-dampak-besar-ke-ekonomi-indonesia 